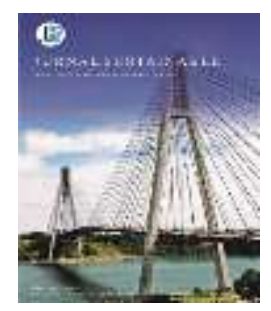

\title{
Rancang Bangun Sistem Kontrol pH Air pada Palka Ikan Muatan Hidup menggunakan Mikrokontroler dan LabVIEW
}

\author{
Trimas Manalu', Rozeff Pramana ${ }^{2}$, Eko Prayetno ${ }^{3}$, Sapta Nugraha, ${ }^{4, *}$ \\ 1,2,3,4 Jurusan Teknik Elektro, Fakultas Teknik, Universitas Maritim Raja Ali Haji \\ 1,2,3,4 Jl. Politeknik Senggarang, Tanjungpinang 29100 \\ *Corresponding Author: saptanugraha@umrah.ac.id
}

\begin{abstract}
The live fish storege currently is not able to control the $\mathrm{pH}$ parameters of the water according to the fish's living environment. $\mathrm{pH}$ needs to be considered so that fish can survive. The purpose of this research is to design a system that can control the $\mathrm{pH}$ of water in fish hatch using a microcontroller and LabVIEW. The test is carried out on the hatch with dimensions of $90 \mathrm{~cm} \times 65$ $\mathrm{cm} \times 50 \mathrm{~cm}$. Monitoring changes in $\mathrm{pH}$ values in real time is done through LCD and LabVIEW. This device is equipped with an LED indicator that can indicate the condition of the relay outside of the LaBVIEW software. The difference in sensor readings designed with a standard measuring instrument is only around 0.05 . The appearance process of the sensor reading value on the LCD and LabVIEW runs well with a response time reading of about 0.5 seconds and with a response time in controlling the relay about 0.3 seconds. Fish can survive using a control system designed during the testing process within $2 \times 24$ hours. The reading value from the sensor will be stored in real time as long as the LabVIEW software runs.
\end{abstract}

Keywords-Microcontroller, LabVIEW, pH Control System, Fish Palka.

Intisari- Palka ikan muatan hidup saat ini tidak mampu mengontrol parameter $\mathrm{pH}$ air sesuai dengan lingkungan hidup ikan. pH perlu diperhatikan agar ikan dapat bertahan hidup. Tujuan dari penelitian ini adalah merancang bangun sistem yang dapat mengontrol $\mathrm{pH}$ air pada palka ikan menggunakan mikrokontroler dan LabVIEW. Pengujian dilakukan pada palka dengan dimensi 90 $\mathrm{cm}$ x $65 \mathrm{~cm}$ x $50 \mathrm{~cm}$. Monitoring perubahan nilai $\mathrm{pH}$ secara real time ditampilkan menggunakan LCD dan LabVIEW. Perangkat ini dilengkapi dengan indikator LED yang dapat mengindikasikan kondisi dari relay diluar dari perangkat lunak LaBVIEW. Selisih pembacaan sensor yang dirancang dengan alat ukur standar hanya berkisar 0,05 . Proses penampilan nilai pembacaan sensor pada LCD dan LabVIEW berjalan baik dengan waktu respon pembacaan sekitar 0,5 detik dan respon waktu dalam mengendalikan relay sekitar 0,3 detik. Ikan dapat bertahan hidup dengan menggunakan sistem kontrol yang dirancang selama proses pengujian dalam waktu $2 \times 24$ jam. Nilai pembacaan dari sensor akan tersimpan secara real time selama perangkat lunak LabVIEW berjalan. Kata kunci - Mikrokontroler, LabVIEW, Sistem Kontrol pH, Palka Ikan. 
Manalu, dkk., Rancang Bangun Sistem Kontrol pH Air pada Palka Ikan Muatan Hidup menggunakan Mikrokontroller dan LabVIEW

\section{Pendahuluan}

Sektor perikanan mempunyai peranan yang penting dan strategis dalam pembangunan perekonomian nasional (KEPMEN-KP No. 52A tahun 2013). Badan Pusat Statistik tahun 2017 menunjukkan bahwa konsumsi ikan di setiap provinsi mengalami peningkatan sebesar $21.9 \%$ dalam periode 2014-2017 dengan preferensi produk yang dikonsumsi, yaitu Ikan segar $76 \%$, Kelompok Ikan dalam Makanan Jadi (KIMJ) 19\%, Ikan Asin Diawetkan 15\%. Salah satu hasil perikanan dengan nilai ekonomis tinggi dalam sektor perikanan budidaya adalah ikan Kerapu hidup. Kapal Pengangkutan Ikan Hidup (KPIH) diperlukan untuk memenuhi permintaan ikan Kerapu hidup. Keberhasilan hidup ikan pada saat proses pengangkutan menjadi masalah yang sering dihadapi oleh KPIH. Agar ikan dapat bertahan dalam kondisi hidup maka harus diperhatikan beberapa faktor, yaitu kualitas ikan, suhu air, pH air, salinitas air, oksigen terlarut pada air, dan kadar amonia (kekeruhan) pada air [1]. Palka ikan muatan hidup saat ini rata-rata menggunakan sistem sirkulasi atau pergantian air terus-menerus melalui katup-katup pipa yang dikendalikan oleh pompa air dan ada menggunakan kompresor untuk mensuplai oksigen kedalam air [1]. Namun, palka ikan yang ada saat ini tidak mampu me-monitoring dan melakukan pengontrolan parameter $\mathrm{pH}$ air sesuai dengan parameter lingkungan hidup ikan. Hal ini menjadi sebuah masalah pada sistem pengontrolan kualitas air pada palka ikan saat ini dalam mempertahankan hidup ikan.

Perancangan sebuah sistem kontrol yang dapat mengontrol parameter $\mathrm{pH}$ air pada palka muatan ikan hidup dapat mempertahankan keberhasilan hidup ikan. Mikrokontroler akan digunakan sebagai proses sistem kontrol sedangkan sensor $\mathrm{pH}$ digunakan sebagai pengukur parameter $\mathrm{pH}$ air yang dibutuhkan. Penambahan sistem monitoring pada sistem kontrol menggunakan sebuah PC (personal computer) dan perangkat lunak LabVIEW membuat kinerja lebih optimal. Perangkat lunak LabVIEW akan menampilkan seluruh proses dari mikrokontroler dalam bentuk visual dan direkam dalam bentuk data.

\section{KAJIAN LITERATUR}

Kajian terdahulu terkait judul penelitian ini sebelumnya pernah dilakukan oleh [2] dengan judul "Rancang Bangun Instrumentasi Autonomous Pengukuran Parameter Fisik Laut". Penelitian ini bertujuan untuk merancang dan membuat suatu instrumen autonomous untuk mengukur parameter fisik laut. Pengukuran parameter fisik laut dilakukan dengan alat ukur menggunakan mikrokontroler Arduino Yun ATMega32 versi surface mounting device (SMD) yang dilengkapi sensor suhu (DS18B20), $\mathrm{pH}$ meter, dan konduktivitas (electrical conductivity meter). Hasil pengujian yang dilakukan menunjukkan pengukuran kualitas air tawar memiliki nilai suhu rata-rata sebesar 26.58 ${ }^{\circ} \mathrm{C}$, pH 7.63, dan salinitas 0 , sedangkan pengukuran kualitas air laut dengan rata-rata suhu sebesar $27.42{ }^{\circ} \mathrm{C}, \mathrm{pH} 8.06$, dan salinitas $31.99 \%$.

Penelitian selanjutnya [3] dengan judul "Rancang Bangun Sistem Pendeteksi Kualitas Air Menggunakan Metode Fuzzy Logic". Penelitian ini melakukan perancangan sistem pengontrolan kualitas air dengan menggunakan sensor $\mathrm{pH}$ dan LDR yang dikontrol menggunakan Arduino Mega untuk mengetahui kualitas air yang layak untuk di minum manusia. Menggunakan sistem ini, akurasi pengukuran $\mathrm{pH}$ $>80 \%$, terutama pada $\mathrm{pH}$ bernilai 7 mencapai $94.40 \%$, dan pada system ini $\mathrm{pH}$ yang di anggap memenuhi kualitas air bernilai antara 6,5 - 7,5 dan alat ini dapat mengukur tingkat kekeruhan air pada rentang 0-200 dengan jarak pencahayaan LED dengan sensor LDR sebesar $10 \mathrm{~cm}$. 
Penelitian selanjutnya [4] dengan judul "Pengontrolan Suhu Air Pada Kolam Pendederan dan Pembenihan Ikan Nila Berbasis Arduino". Penelitian ini membahas tentang sistem pengontrolan suhu air menggunakan Arduino yang kemudian hasil pengukuran disimpan didalam sebuah database. Pengontrolan dilakukan secara otomatis dan dapat mempertahankan nilai suhu selama 24 jam.

Penelitian selanjutnya [1] dengan judul "Perancangan Kapal Angkut Ikan Hidup (KAIH) Ukuran 300 GT Sistem Terbuka untuk Ikan Kerapu". Penelitian ini membahas tentang perancangan sistem palka ikan untuk mempertahankan survival ratio ikan dengan menjaga konsentrasi oksigen, menjaga kebersihan air, dan menjaga $\mathrm{pH}$ air sesuai ketahanan jenis ikan. Untuk mempertahankan nilai beberapa parameter kualitas air tersebut, maka penelitian ini menggunakan metode palka ikan sistem terbuka dengan meninjau keluar masuk air laut, sistem pengolahan air, dan sistem sirkulasinya. Penelitian ini menggunakan Sinar UV dengan panjang gelombang $254 \mathrm{~nm}$ dan dosis $30 \mathrm{mWs} / \mathrm{cm}^{2}$ untuk pengolahan airnya, serta penggunaan aerator berkapasitas $366 \mathrm{cfm}$ untuk menambah kadar oksigen di dalam tangki.

Penelitian selanjutnya [5] dengan judul "Rancang Bangun Prototype Pemantauan Kadar pH dan Kontrol Suhu Serta Pemberian Pakan Otomatis pada Budidaya Ikan Lele Sangkuriang Berbasis IoT". Penelitian ini melakukan perancangan prototype untuk memantau suhu dan $\mathrm{pH}$ air menggunakan Arduino Uno R3 dan modul ethernet shield sebagai pengirim ke IoT Cloud. Penelitian ini berhasil memperoleh hasil parameter yang dipantau meliputi suhu menggunakan sensor DS18B20, kadar $\mathrm{pH}$ air menggunakan sensor $\mathrm{pH}$ Meter dan proses otomatisasi pemberian pakan menggunakan motor servo.

\section{METODE PENELITIAN}

\section{A. Metode Pengumpulan Data}

1) Studi Literatur: Metode ini dilakukan dengan studi pustaka yang dapat berupa bukubuku referensi, e-book, jurnal-jurnal, dan yang terkait dengan kajian terdahulu untuk mendukung perancangan pada penelitian ini.

2) Observasi: Metode ini dilakukan dengan meninjau langsung kelapangan tentang permasalahan-permasalahan yang berkaitan dengan pengontrolan kualitas air pada palka ikan muatan hidup pada kondisi sebenarnya.

3) Perancangan: Metode ini dilakukan dengan perancangan sensor $\mathrm{pH}$, perancangan perangkat pengolah data, perancangan perangkat pompa air dan aerator, perancangan LCD dan indikator LED, perancangan perangkat lunak Arduino, dan perancangan perangkat lunak LabVIEW.

4) Pengujian: Metode ini dilakukan untuk mendapatkan data melalui perangkat yang telah dirancang.

\section{B. Perancangan Sistem}

Perancangan sistem terdiri dari tiga bagian, yaitu bagian input, proses, dan keluaran. Pada penelitian ini yang dimaksud bagian input, yaitu sensor $\mathrm{pH}$. Bagian proses, yaitu menggunakan mikrokontroler Arduino Mega 2560. Bagian keluaran, yaitu terdiri dari pompa air, aerator, LCD, Indikator LED, dan tampilan LabVIEW.

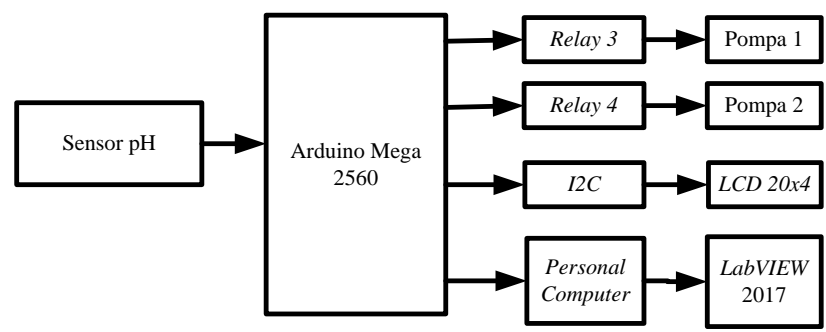

Gambar 1. Blok Diagram Perancangan Perangkat 
Gambar 1 merupakan blok diagram perangkat secara keseluruhan untuk sistem kontrol $\mathrm{pH}$ air pada palka ikan muatan hidup. Pada perangkat ini juga terdapat beberapa perangkat keras sebagai pendukung kinerja blok diagram di atas, yaitu relay, adaptor, LED, dan rangkaian penurun tegangan. Perangkat keras ini akan bekerja seperti yang ditentukan.

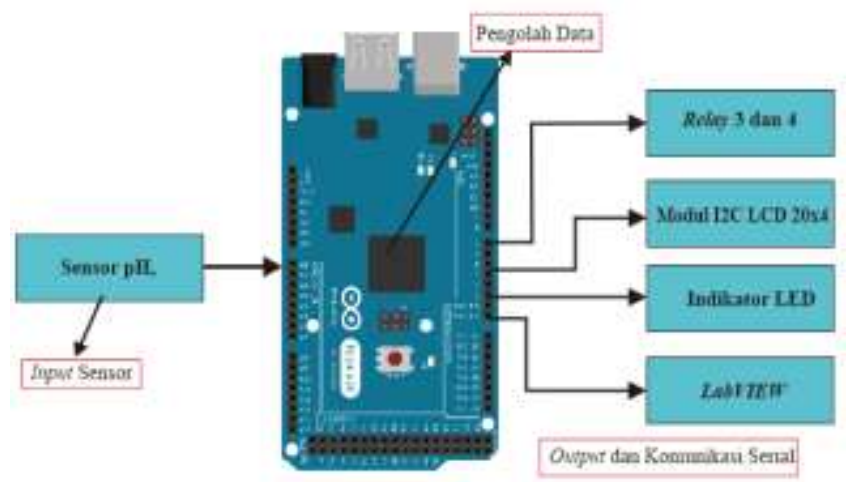

Gambar 2. Perancangan Perangkat Keseluruhan

\section{Cara Kerja Perangkat}

Cara kerja dari perangkat penelitian ini dimulai dengan menginisialisasi port antarmuka mikrokontroler Arduino dan LabVIEW, kemudian mikrokontroler akan melakukan proses pembacaan nilai $\mathrm{pH}$ melalui pembacaan sensor yang sudah terhubung pada Arduino Mega 2560. Mikrokontroler akan selalu membaca data sensor yang ada selama alat digunakan dan hasil pembacaan sensor akan ditampilkan pada LCD dan perangkat lunak LabVIEW.

Nilai pembacaan dari sensor akan digunakan untuk mengontrol keluaran sistem seperti pompa air, aerator dan LED. Hasil pembacaan sensor $\mathrm{pH}$ digunakan untuk mengontrol tingkat $\mathrm{pH}$ air melalui keluaran pompa 1, pompa 2, dan aerator. Penggunaan perangkat lunak LabVIEW dijadikan sebagai antarmuka mikrokontroler dengan sebuah tampilan visual yang dapat lebih memudahkan untuk pemantauan kinerja dari sistem perangkat.

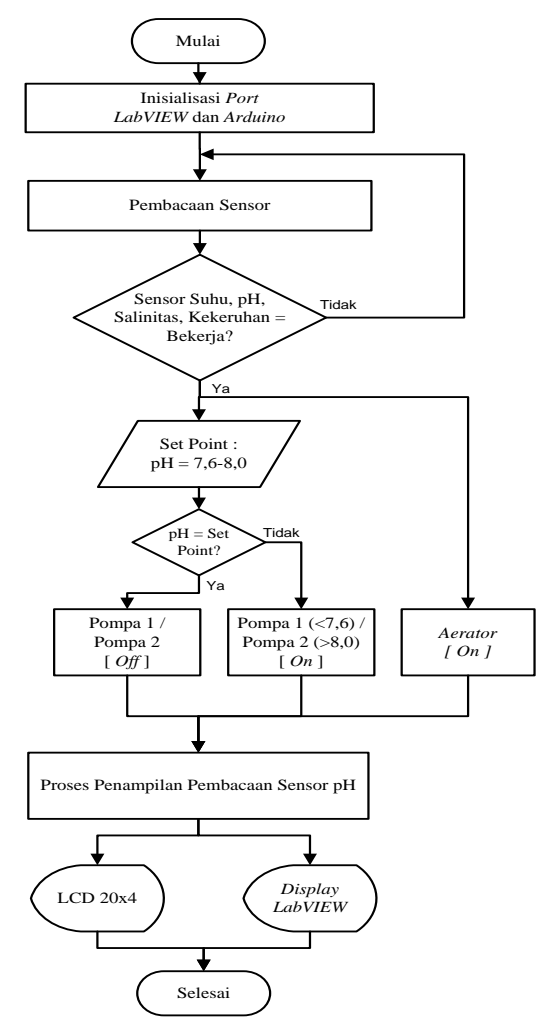

Gambar 3. Diagram Alir Cara Kerja Sistem Perangkat

Pada Gambar 3 dapat dilihat ketika nilai pembacaan dari sensor $\mathrm{pH}$ diluar dari nilai setpoint yang sudah ditentukan, maka kondisi keluaran yang dikendalikan relay akan aktif bekerja. Sedangkan ketika nilai pembacaan sensor didalam rentang nilai setpoint, maka kondisi keluaran yang dikendalikan relay tidak akan aktif bekerja. Pada penelitian ini, pompa aerator akan bekerja selama sistem bekerja. Hal ini dilakukan agar mempercepat proses pencampuran antara larutan-larutan yang digunakan dengan air yang ada pada palka ikan.

\section{PenguJian dan ANALISIS}

\section{A. Pengujian Sensor $p H$}

Pengujian sensor $\mathrm{pH}$ bertujuan untuk mengetahui apakah sensor $\mathrm{pH}$ telah berfungsi dengan baik dan sesuai dengan perancangan yang telah dibuat atau tidak. Untuk mendapatkan nilai $\mathrm{pH}$ yang mendekati sebenarnya, maka terlebih dahulu dilakukan kalibrasi dengan membandingkan pembacaan sensor $\mathrm{pH}$ dengan alat ukur standar. Pengujian ini menggunakan beberapa sampel yang dijadikan sebagai acuan 
nilai pengukuran, yaitu $p H$ Buffer Powder 4.00, pH Buffer Powder 6.86, pH Buffer Powder 9.18, air cuka, soda kue, dan air sabun.

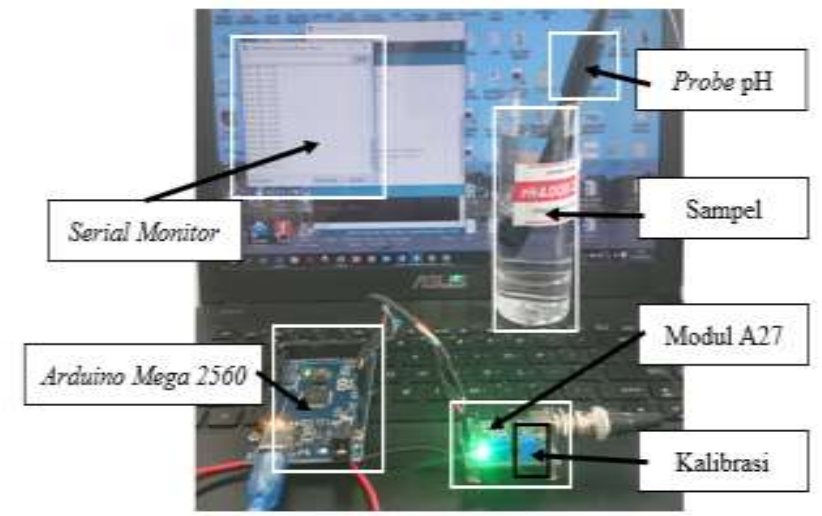

Gambar 4. Pembacaan Sensor pH Melalui Serial Monitor

Proses kalibrasi dilakukan dengan merekam terlebih dahulu nilai $\mathrm{pH}$ pada sampel menggunakan $\mathrm{pH}$ meter standar. Kemudian sampel diukur kembali menggunakan sensor $\mathrm{pH}$. Kalibrasi dilakukan dengan memutar potensio kalibrasi pada modul A27 agar nilai pembacaan sensor sama dengan pembacaan $\mathrm{pH}$ meter. Pemutaran potensio kalibrasi dapat dilakukan searah jarum jam ataupun berlawanan hingga nilai yang terbaca oleh sensor sama atau mendekati alat ukur $\mathrm{pH}$ meter standar.

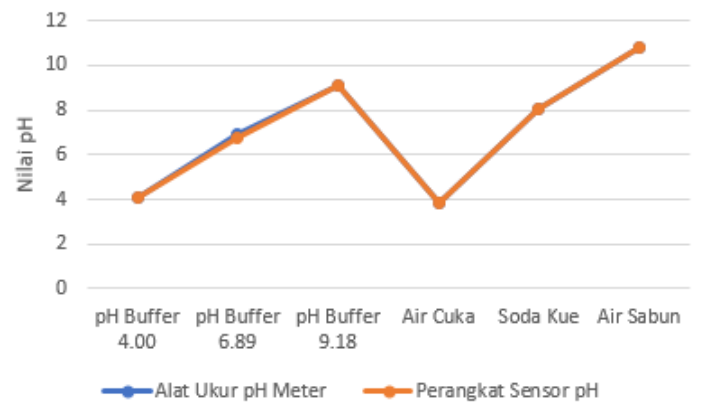

Gambar 5. Kalibrasi Nilai Sensor pH Terhadap Alat Ukur Standar $\mathrm{pH}$ Meter

Pada Gambar 5 dapat dilihat bahwa grafik nilai pembacaan perangkat sensor $\mathrm{pH}$ berbanding lurus dengan nilai alat ukur $\mathrm{pH}$ meter.

Tabel 1. Kalibrasi Perangkat Sensor $\mathrm{pH}$ dengan $\mathrm{pH}$ Meter

\begin{tabular}{ccccccc}
\hline No & Sampel & $\begin{array}{c}\text { pH } \\
\text { Meter }\end{array}$ & $\begin{array}{c}\text { Sensor } \\
\text { pH }\end{array}$ & $\begin{array}{c}\text { Tegangan } \\
\text { Terukur }\end{array}$ & $\begin{array}{c}\text { Nilai } \\
\text { ADC }\end{array}$ & $\begin{array}{c}\text { Selisih } \\
\text { Nilai }\end{array}$ \\
\hline 1 & $\mathrm{pH} \mathrm{Buffer} 4.00$ & 4,056 & 4,06 & $2,964 \mathrm{~V}$ & 607 & 0,004 \\
2 & $\mathrm{pH} \mathrm{Buffer} 6.89$ & 6,875 & 6,75 & $2,519 \mathrm{~V}$ & 516 & 0,125 \\
3 & $\mathrm{pH} \mathrm{Buffer} 9.18$ & 8,086 & 9,08 & $2,104 \mathrm{~V}$ & 429 & 0,051 \\
4 & Air Cuka & 3,865 & 3,83 & $2,998 \mathrm{~V}$ & 612 & 0,035 \\
5 & Soda Kue & 9,131 & 8,07 & $2,290 \mathrm{~V}$ & 468 & 0,016 \\
6 & Air Sabun & 10,839 & 10,77 & $1,826 \mathrm{~V}$ & 375 & 0,069 \\
\hline
\end{tabular}

Berdasarkan data pada Tabel 1, error pembacaan sensor $\mathrm{pH}$ ini cukup kecil. Jika dirata-rata selisih hanya sekitar $0,05 \mathrm{pH}$. Pengujian ini membuktikan bahwa sensor $\mathrm{pH}$ berjalan dengan baik. Pengujian menggunakan osiloskop dilakukan untuk melihat bentuk sinyal yang diproyeksikan keluaran sensor terhadap perubahan nilai $\mathrm{pH}$.

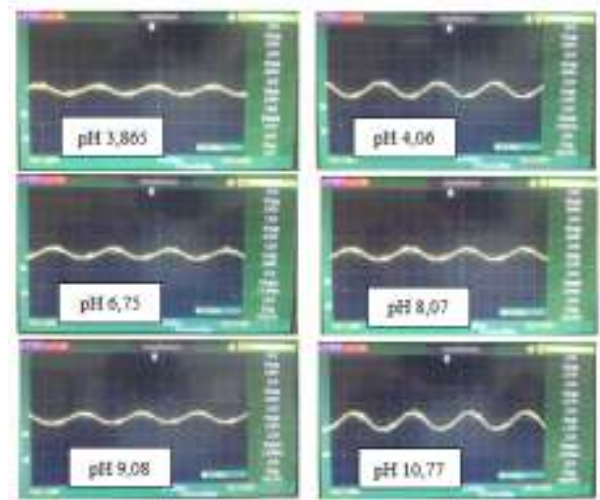

Gambar 6. Pengujian Sensor pH Menggunakan Osiloskop

Sinyal yang diproyeksikan osiloskop dari keluaran sensor $\mathrm{pH}$ berbentuk gelombang sinus. Artinya, keluaran dari sensor $\mathrm{pH}$ berupa sinyal analog. Hubugan antara nilai $\mathrm{pH}$ yang terukur dengan perubahan nilai tegangan keluaran sensor $\mathrm{pH}$, yaitu ketika nilai $\mathrm{pH}$ semakin tinggi maka nilai tegangan akan semakin rendah. Jika dilihat besar tegangan dari gelombang sinyal akan semakin menurun pada saat nilai $\mathrm{pH}$ semakin tinggi. Setelah dilakukan pengujian kalibrasi sensor $\mathrm{pH}$, maka selanjutnya melakukan pengujian sensor $\mathrm{pH}$ pada palka ikan. Hal ini dilakukan untuk mengetahui respon dari hasil pembacaan sensor $\mathrm{pH}$ terhadap keluaran sistem.

Tabel 2. Hasil Pengujian Sensor pH Pada Palka Ikan

\begin{tabular}{|c|c|c|c|c|}
\hline \multirow[b]{2}{*}{ No } & \multirow[b]{2}{*}{ Seasor pH } & \multirow[b]{2}{*}{ Bentuk Sinyal } & \multicolumn{2}{|c|}{ Statm Ouptut } \\
\hline & & & $\begin{array}{l}\text { Pompa 1 } \\
\text { (Relay 3, } \\
\text { L.FD 3) }\end{array}$ & $\begin{array}{l}\text { Pomps } 2 \\
\text { (Relloy } 4, \\
\text { LDD } 4 \text { ) }\end{array}$ \\
\hline 1 & 7,59 & & Altif & Non Aktif \\
\hline 2 & 7,60 & & Nion Alktif & Non Aktif \\
\hline 3 & 7,70 & & Non Aktif & Non Aktif \\
\hline 4 & 7,90 & & Non Aktif & Non Aktf \\
\hline 5 & 8,00 & & Non Aktif & Non Aktif \\
\hline 6 & 8,01 & & Non Aktif & Aktif \\
\hline
\end{tabular}


Berdasarkan hasil pengujian sensor $\mathrm{pH}$ pada Tabel 2 dapat dilihat bahwa jika $\mathrm{pH}$ yang terukur dalam rentang 7,60 sampai 8,00, maka pompa 1 dan pompa 2 beserta indikator LED 3 dan 4 tidak akan aktif. Namun, jika pH yang terukur dibawah 7,60 $\mathrm{pH}$, maka pompa 1 akan memompa larutan basa kedalam palka ikan dan indikator LED 3 akan otomatis aktif bekerja. Kemudian, jika $\mathrm{pH}$ yang terukur di atas $8,00 \mathrm{pH}$, maka pompa 2 akan memompa larutan asam kedalam palka ikan dan indikator LED 4 akan otomatis aktif bekerja.

\section{B. Pengujian Perangkat Pengolah Data}

Pengujian pengolah data dilakukan untuk mengetahui apakah perangkat keras Arduino dapat bekerja dengan baik saat melakukan proses pengolahan data. Pengujian juga dilakukan untuk mengetahui respon Arduino Mega 2560 terhadap masukan dan keluaran pada perangkat sistem. Setiap pin input sensor akan diukur nilai tegangannya dan melihat bentuk sinyal yang diproyeksikan dari setiap inputan sensor. Kemudian setiap keluaran sistem akan diukur nilai tegangannya dan melihat respon setiap keluaran dengan memproyeksikan bentuk sinyal yang ada pada setiap respon keluaran.

Tabel 3. Hasil Pengujian Pengolah Data Arduino

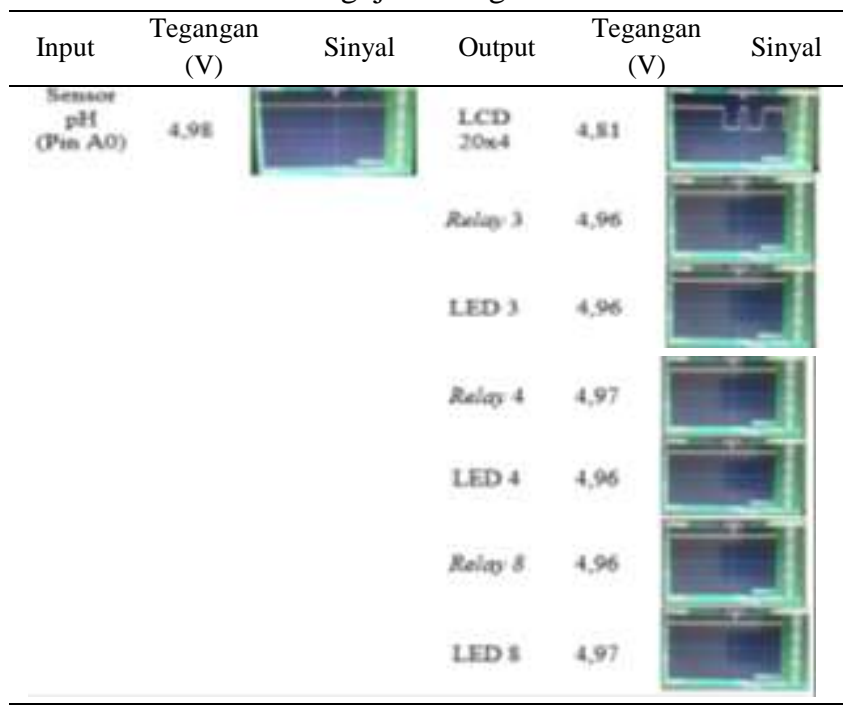

Pengujian berikutnya dilakukan pada pin input analog Arduino Mega 2560. Pengujian ini dilakukan untuk mengetahui resolusi perbandingan antara nilai ADC yang terbaca Arduino dengan nilai tegangan yang terukur. Pin input analog dapat mengubah nilai analog berbentuk sinyal voltase ke dalam bentuk digital. Pin input analog pada Arduino memiliki resolusi nilai ADC sebesar 10 bit. Artinya tegangan 0-5V mampu dikonversikan kedalam data digital berkisar dari 0-1023. Pengujian ini menggunakan potensio sebagai sampel input tegangan. Pada pin input analog akan dimasukkan tegangan mulai dari 0V sampai $5 \mathrm{~V}$.

Tabel 4. Hubungan Input Tegangan Terhadap Nilai ADC

\begin{tabular}{ccc}
\hline$N_{0}$ & Tegangan $(\mathbf{V})$ & Nilai ADC \\
\hline 1 & 5,00 & 1023 \\
2 & 4,50 & 928 \\
4 & 4,00 & 826 \\
5 & 3,50 & 722 \\
6 & 3,00 & 617 \\
7 & 2,50 & 515 \\
8 & 2,00 & 408 \\
9 & 1,50 & 307 \\
10 & 1,00 & 205 \\
11 & 0,50 & 101 \\
12 & 0,00 & 0 \\
\hline
\end{tabular}

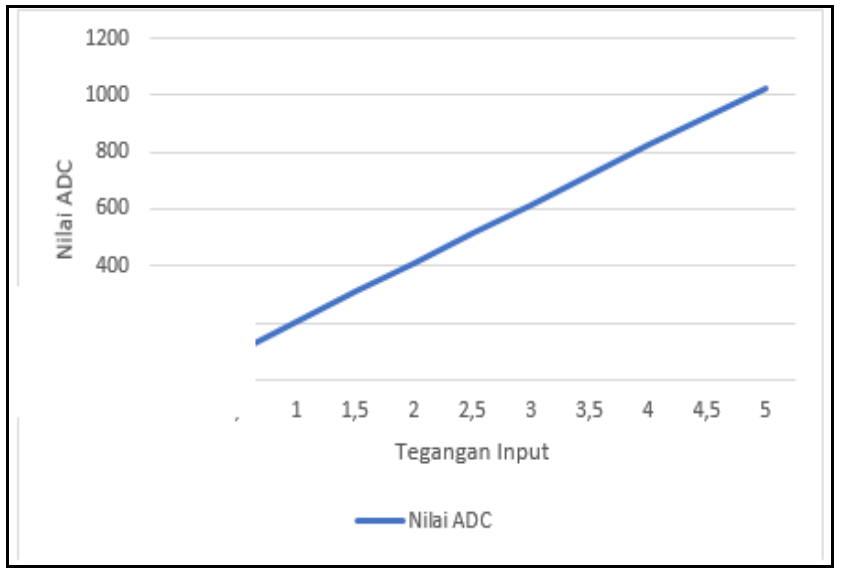

Gambar 7. Hubungan Input Tegangan Terhadap ADC

Berdasarkan data tersebut bahwa jika setiap tegangan input analog diturunkan sebesar $0,5 \mathrm{~V}$ maka nilai ADC yang terbaca akan turun dengan nilai rata-rata sekitar 100 .

\section{Pengujian LCD dan Indikator LED}

Pengujian LCD bertujuan untuk mengetahui apakah perangkat tersebut telah berfungsi dengan baik dan sesuai dengan perancangan yang telah dibuat atau tidak. Pengujian LCD dilakukan dengan melakukan 
pengukuran tegangan pada kaki I2C pada LCD. Pengukuran tegangan dilakukan untuk mengetahui apakah LCD dapat bekerja dengan baik.

Tabel 5. Hasil Pengujian LCD

\begin{tabular}{ccccc}
\hline $\begin{array}{c}\text { Catu Daya } \\
\text { (V) }\end{array}$ & Pin & $\begin{array}{c}\text { Tegangan } \\
\text { Terukur (V) }\end{array}$ & $\begin{array}{c}\text { Tegangan } \\
\text { Sumber (V) }\end{array}$ & Selisih (V) \\
\hline 5 & VCC & 4,81 & 4,98 & 0,17 \\
5 & SDA & 4,29 & 4,98 & 0,69 \\
5 & SCL & 4,84 & 4,98 & 0,14 \\
\hline
\end{tabular}

Berdasarkan data pada Tabel 5 bahwa tegangan yang terukur pada setiap kaki LCD memiliki selisih cukup kecil. Pengujian ini membuktikan bahwa perangkat LCD dapat berjalan dengan baik.

Selanjutnya pengujian LED bertujuan untuk mengetahui apakah LED dapat berfungsi dan bekerja dengan optimal. Parameter yang akan diuji yaitu tegangan pada LED untuk mengetahui apakah LED dapat menyala dan bekerja dengan baik.

Tabel 6. Hasil Pengujian Indikator LED

\begin{tabular}{|c|c|c|c|c|}
\hline $\begin{array}{l}\text { Catu } \\
\text { Dasa }\end{array}$ & $\begin{array}{l}\text { Kandisi } \\
\text { LED }\end{array}$ & $\begin{array}{l}\text { Teganeaa } \\
\text { Terukur (N) }\end{array}$ & Beatuk Sinyal & $\begin{array}{c}\text { Selkib } \\
\text { (V) }\end{array}$ \\
\hline 5 & Non Aktif & 0 & 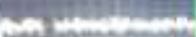 & 5 \\
\hline 5 & Aktif & 2,67 & & 2,33 \\
\hline
\end{tabular}

Tabel 6 menunjukkan pengujian LED dengan memberikan tegangan ke kaki anoda pada LED. Tegangan pada LED terukur sebesar 2,67V dikarenakan adanya resistor yang berguna membatasi tegangan yang masuk ke dalam kaki anoda pada LED.

Pengujian perangkat LCD dan indikator LED bertujuan untuk mengetahui kinerja LCD dalam menampilkan proses pembacaan sensor melalui perangkat pengolah data. Berdasarkan pengujian yang telah dilakukan, hasil pembacaan sensor dapat ditampilkan pada perangkat LCD dan setiap perubahan dapat diindikasikan pada indikator LED. Pengujian ini membuktikan bahwa perangkat LCD dapat berjalan dengan baik.
Tabel 7. Hasil Pengujian Perangkat LCD dan LED

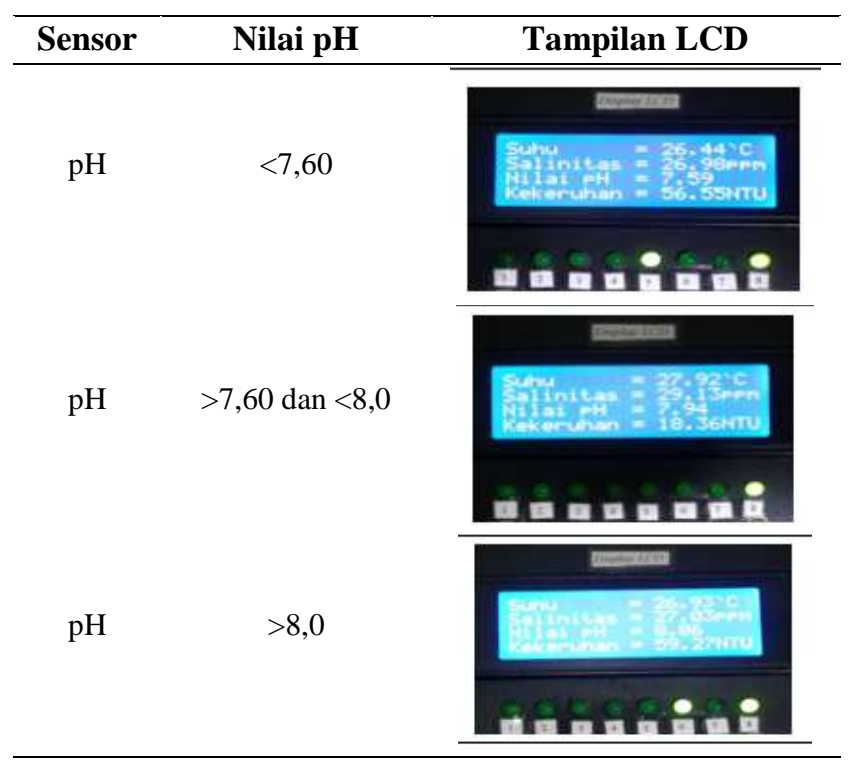

\section{Pengujian Perangkat Lunak Arduino}

Pengujian ini dilakukan untuk mengetahui apakah source code program yang digunakan pada Arduino dan LabVIEW dapat memproses data hasil pembacaan sensor dan mengeksekusinya dengan baik. Pengujian ini dilakukan untuk melihat respon eksekusi program yang dilakukan Arduino. Sebelum meng-upload listing program keseluruhan, terlebih dahulu harus menentukan Board dan Port yang digunakan pada perangkat lunak Arduino. Pada pengujian ini menggunakan pilihan Board Arduino Mega 2560 dan Port COM6. Hal ini dilakukan agar perangkat lunak Arduino dapat melakukan komunikasi dengan perangkat keras Arduino.

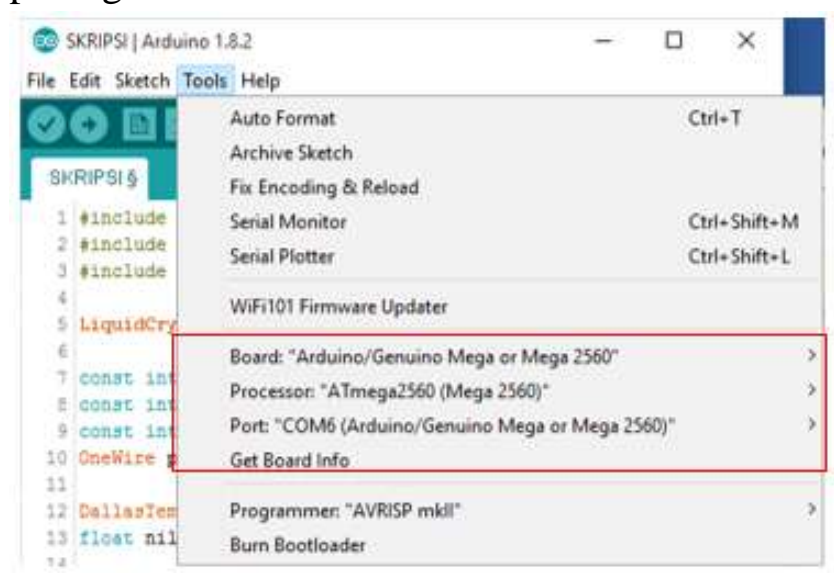

Gambar 7. Pengaturan Serial Port Arduino 
Manalu, dkk., Rancang Bangun Sistem Kontrol pH Air pada Palka Ikan Muatan Hidup menggunakan Mikrokontroller dan LabVIEW

Berdasarkan hasil pengujian pada perangkat lunak Arduino, listing program berhasil di upload ke perangkat keras Arduino selama 23 detik. Lamanya proses upload dipengaruhi oleh besarnya data yang akan di upload. Perubahan nilai pembacaan sensor yang akan dikirimkan pada LCD dan LabVIEW membutuhkan delay sekitar 0,5 detik dan respon Arduino terhadap relay dan indikator relay sekitar 0,3 detik.

\section{E. Pengujian Perangkat Lunak LabVIEW}

Pengujian perangkat lunak LabVIEW dilakukan untuk melihat apakah program LabVIEW yang dibuat dapat bekerja dengan baik. Untuk dapat berkomunikasi dengan perangkat keras Arduino Mega 2560, maka LabVIEW memerlukan fungsi VISA configure serial port. Fungsi ini digunakan untuk mengatur setting komunikasi serial di awal sebelum komunikasi dilangsungkan. Blok diagram akan mengalami error ketika serial port pada fungsi ini tidak sesuai dengan port Arduino yang digunakan. Pengaturan VISA configure serial port pada pengujian ini dapat dilihat pada Gambar 8.

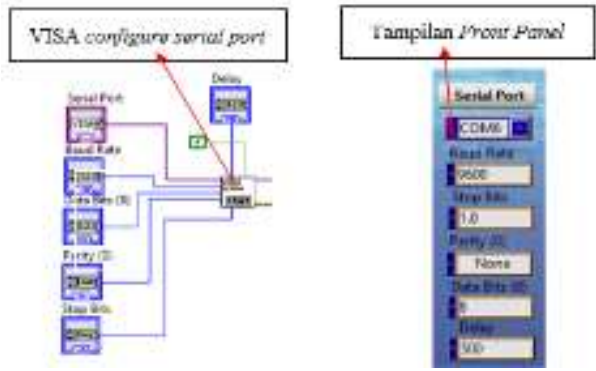

Gambar 8. Konfigurasi Serial Data Program LabVIEW

Pada blok diagram, fungsi VISA Flush I/O buffer digunakan untuk membersihkan isi buffer sebelumnya dengan mengirimkan semua isinya ke alat yang ditentukan oleh VISA resource name. Hal ini perlu dilakukan agar pada saat program dijalankan kembali, data sebelumnya yang sudah masuk tidak akan ditampilkan kembali.

\section{- \\ Gambar 9. VISA Flush I/O Buffer}

Fungsi wait until next ms multiple digunakan dalam blok diagram dengan tujuan untuk memberikan delay pada program. Hal ini dilakukan agar data yang diproses dapat berjalan baik. Besarnya nilai delay disesuaikan dengan lamanya waktu perangkat keras Arduino dalam mengirim data ke LabVIEW.

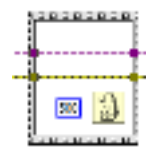

Gambar 10. Wait Until Next ms Multiple

VISA bytes at serial port pada blok diagram digunakan untuk menghitung banyaknya byte yang terdapat dalam buffer di saluran port serial yang ditentukan.

$$
\text { Bytes at Port? }
$$

Gambar 11. VISA Bytes at Serial Port

Data hasil pengolahan Arduino yang dikirimkan dalam bentuk bytes at ports akan dibaca dengan menggunakan fungsi VISA Read. Fungsi ini digunakan untuk membaca sejumlah byte data dari alat atau antarmuka perangkat keras yang ditentukan oleh VISA resource name.

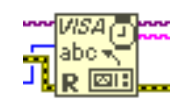

Gambar 12. VISA Read

Seluruh data hasil pengukuran sensor yang dikirimkan ke LabVIEW akan dibaca dengan menggunakan VISA Read dalam bentuk buffer berupa string. Data yang dibaca harus dipisah sesuai dengan nilai pengukuran masingmasing yang telah di inisialkan. Untuk nilai buffer dengan awalan "P" diteruskan ke tampilan nilai $\mathrm{pH}$. Pemisahan data sesuai dengan inisial yang telah dibuat dilakukan dengan menggunakan fungsi Match Pattern. Fungsi Sting to Number digunakan untuk mengubah data dalam bentuk string menjadi number, sehingga dapat ditampilkan dalam grafik 
maupun indikator. Berikut adalah program LabVIEW dalam menampilkan hasil pengukuran sensor dan proses dari sistem kontrol.

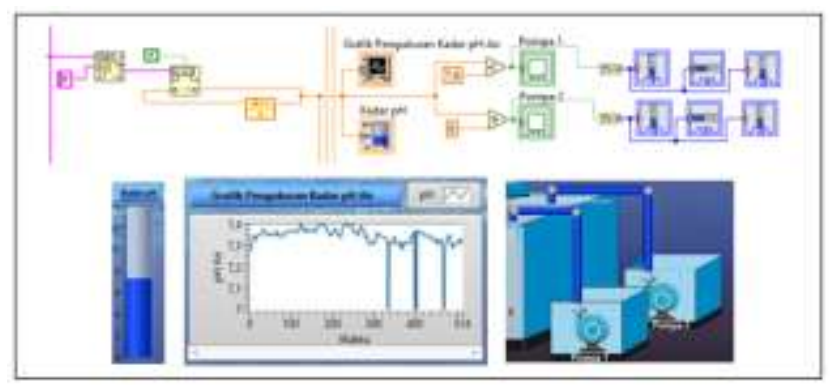

Gambar 13. Program Tampilan Pengontrolan $\mathrm{pH}$ pada Perangkat Lunak LabVIEW

VISA close digunakan untuk menutupi komunikasi dengan perangkat keras Arduino oleh VISA resource name.

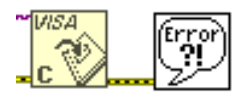

Gambar 14. VISA Close

Pengujian pada program penyimpanan data LabVIEW dilakukan untuk mengetahui proses dari penyimpanan data apakah berjalan dengan baik atau tidak. Penyimpanan data dilakukan menggunakan fungsi File Dialog dengan format file excel. Program penyimpanan ini terdiri dari 3 bagian fungsi, yaitu diawali dengan Write to Text File, kemudian Format into File, dan diakhiri dengan Close File.

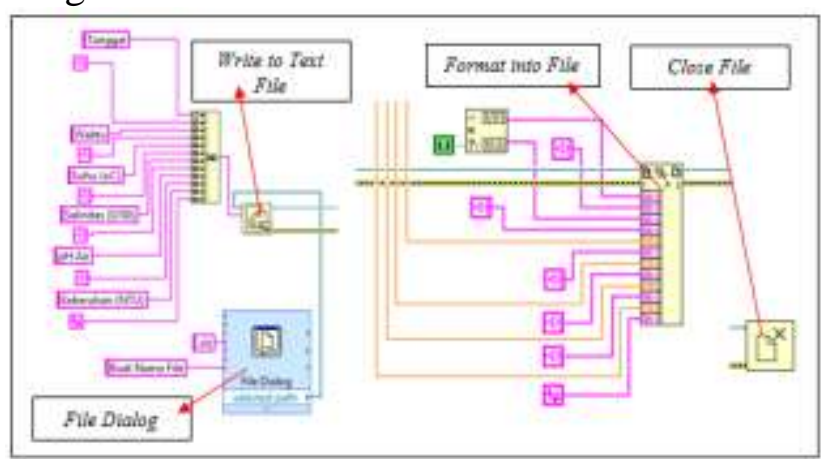

Gambar 15. Program Penyimpanan Data Pada LabVIEW

Berdasarkan hasil pengujian yang telah dilakukan bahwa perangkat lunak LabVIEW dapat bekerja dengan baik. Penentuan waktu delay yang tepat dibutuhkan pada program LabVIEW. Delay yang dibuat pada Arduino diatur sedikit lebih cepat dibandingkan pada program LabVIEW. Sebab, jika waktu delay pada program LabVIEW lebih cepat maka akan terjadi keterlambatan penerimaan data pada serial data LabVIEW. Jika hal itu terjadi maka LabVIEW akan menampilkan data sebagai nilai 0. Namun, jika delay pada Arduino terlalu cepat akan membuat kinerja dari LabVIEW menjadi lambat, dan nilai yang diterima serial data LabVIEW akan menumpuk.

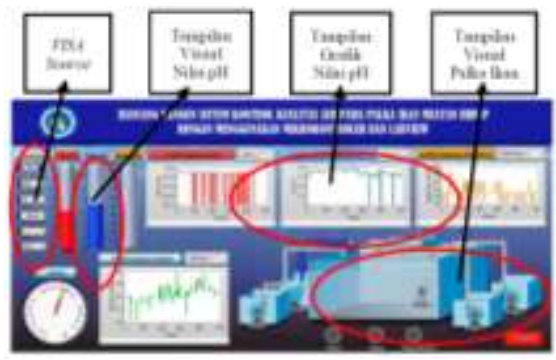

Gambar 16. Pengujian Perangkat Lunak LabVIEW

\section{F. Analisis}

Berdasarkan hasil pengujian yang telah dilakukan pada sensor $\mathrm{pH}$ dapat dianalisis bahwa sensor $\mathrm{pH}$ yang dirancang pada penelitian ini mampu mengontrol $\mathrm{pH}$ pada palka ikan sesuai dengan range Setpoint yang ditentukan dengan nilai penyimpangan cukup kecil sekitar $0,05 \mathrm{pH}$. Pembacaan sensor $\mathrm{pH}$ akan diproses oleh perangkat pengolah data dan menampilkannya pada LCD dan perangkat lunak LabVIEW. Keluaran dari sensor $\mathrm{pH}$ digunakan sebagai nilai Setpoint untuk mengendalikan relay dan indikator LED. Pada saat nilai keluaran sensor $\mathrm{pH}$ yang terbaca $<7,60$ maka mikrokontroler Arduino Mega 2560 akan mengendalikan relay pompa 1 untuk memompa larutan bersifat basa ke dalam palka dan indikator LED 3 aktif bekerja. Ketika nilai keluaran sensor $\mathrm{pH}$ yang terbaca $>8,00$ maka mikrokontroler akan mengendalikan relay pompa 2 untuk memompa larutan bersifat asam ke dalam palka dan indikator LED 4 aktif bekerja. Proses penampilan nilai pembacaan sensor $\mathrm{pH}$ pada LCD dan LabVIEW berjalan baik dengan waktu respon pembacaan sekitar 0,5 detik. Begitu juga dengan respon waktu dalam mengendalikan relay sekitar 0,3 detik. Nilai pembacaan dari sensor $\mathrm{pH}$ akan tersimpan secara real time selama perangkat lunak LabVIEW berjalan. Dari hasil pengujian yang dilakukan selama 5 hari, perangkat sistem mampu mempertahankan $\mathrm{pH}$ 
air pada palka ikan sesuai dengan nilai Setpoint yang dibuat. Selama pengujian dilakukan, sensor $\mathrm{pH}$ yang dirancang memiliki performa yang baik dan mampu mengendalikan $\mathrm{pH}$ di dalam palka ikan sesuai dengan batas-batas nilai Setpoint.

Berdasarkan hasil pengujian keseluruhan yang telah dilakukan bahwa perlu untuk diperhatikan peletakan posisi dari tiap kabel keluaran sistem yang digunakan dengan menyesuaikan terhadap fasa dan netral yang ada pada sumber tegangan. Hal ini dilakukan untuk menjaga agar tidak terjadi kebocoran arus listrik pada palka ikan. Jika terjadi kebocoran arus maka akan mengganggu perkembangbiakan dari ikan Kerapu yang dapat membuat ikan menjadi stres.

Berdasarkan hasil pengujian keseluruhan yang telah dilakukan dengan membandingkan palka menggunakan perangkat sistem dengan palka tidak menggunakan perangkat sistem, didapatkan hasil bahwa perangkat sistem yang dirancang lebih optimal dalam mempertahankan hidup ikan. Selama waktu $2 \times 24$ jam proses pengujian yang dilakukan, ikan dapat bertahan hidup dengan menggunakan perangkat sistem kontrol yang dirancang. Namun, pada palka ikan yang tidak menggunakan perangkat sistem kontrol dapat dilihat dengan kondisi kurang dari $2 \times 24$ jam, ikan di dalam palka tidak dapat bertahan hidup.

Penampilan nilai tiap sensor pada LCD dan perangkat lunak LabVIEW bekerja dengan baik, dengan waktu perubahan setiap pembacaan sensor sekitar 0,5 detik pada LCD dan 1 detik pada LabVIEW. Adanya perbedaan delay perubahan tersebut terjadi karena pada LCD pengiriman data dilakukan secara langsung melalui pin serial data Arduino, sedangkan pada perangkat lunak LabVIEW menggunakan komunikasi serial yang dikirimkan melalui kabel USB. Data hasil pengukuran tiap sensor disimpan ke dalam format Excel.

\section{KESIMPULAN}

Perangkat ini dapat mengontrol parameter $\mathrm{pH}$ air pada palka ikan muatan hidup dengan menggunakan sensor $\mathrm{pH}$ melalui mikrokontroler Arduino Mega 2560 sebagai perangkat pengolah data dan menampilkan proses pengolahan data pada perangkat lunak LabVIEW, sehingga sistem kontrol bekerja lebih optimal. Pengukuran dengan menggunakan sensor $\mathrm{pH}$ memiliki tingkat akurasi rata - rata mencapai 99\% sehingga optimal dalam penerepannya. Perangkat ini dilengkapi dengan LCD 20x4 sebagai display perangkat keras, sehingga dapat dilihat perubahan nilai pembacaa sensor secara real time melalui tampilan LCD yang berada pada palka ikan. Perangkat ini dilengkapi dengan indikator LED yang dapat mengindikasikan kondisi dari relay diluar dari perangkat lunak LaBVIEW. Pada saat nilai keluaran sensor $\mathrm{pH}$ yang terbaca $<7,60$ maka mikrokontroler Arduino Mega 2560 akan mengendalikan relay pompa 1 dan indikator LED 3 untuk aktif bekerja. Ketika nilai keluaran sensor $\mathrm{pH}$ yang terbaca $>8,00$ maka mikrokontroler akan mengendalikan relay pompa 2 dan indikator LED 4 untuk aktif bekerja. Proses penampilan nilai pembacaan sensor pada LCD dan LabVIEW berjalan baik dengan waktu respon pembacaan sekitar 0,5 detik. Begitu juga dengan respon waktu dalam mengendalikan relay sekitar 0,3 detik. Nilai pembacaan dari sensor akan tersimpan secara real time selama perangkat lunak LabVIEW dalam keadaan aktif.

\section{UCAPAN TERIMA KASIH}

Terima kasih disampaikan kepada Universitas Maritim Raja Ali Haji melalui Lembaga Penelitian, Pengabdian Masyarakat, dan Penjaminan Mutu (LP3M) yang telah membiayai penelitian ini dalam skema Penelitian Berbasis Laboratorium.

\section{REFERENSI}

[1] Y. A. Nastiti, A. Baheramsyah, dan S. P. Fitri, "Perancangan Kapal Angkut Ikan Hidup (Kaih) Ukuran 300 Gt Sistem Terbuka Untuk Ikan Kerapu," Pros. Semin. Nas. Kelaut. 2016, hlm. 241-248, Jul 2016. 
[2] H. M. Manik, A. Dwinovantyo, H. Santoso, dan S. Steven, "Rancang Bangun Instrumen Autonomous Pengukur Parameter Fisik Laut," Pros. SNIKO 2015, hlm. 11, Des 2015.

[3] M. Abdullah, E. Susanto, dan P. D. Wibawa, "Rancang Bangun Sistem Pendeteksi Kualitas Air Menggunakan Metode Fuzzy Logic Universitas Telkom," E-Proceeding Eng., vol. 3, no. 2, Agu 2016.

[4] A. Simanjuntak dan R. Pramana, "Pengontrolan Suhu Air Pada Kolam Pendederan dan Pembenihan Ikan Nila
Berbasis Arduino," J. Sustain., vol. 4, no. 1, Mei 2013.

[5] Al Qalit, Fardian, dan Aulia Rahman, "Rancang Bangun Prototipe Pemantauan Kadar pH dan Kontrol Suhu Serta Pemberian Pakan Otomatis pada Budidaya Ikan Lele Sangkuriang Berbasis IoT," KITEKTRO J. Online Tek. Elektro, vol. Vol.2 No.3, hlm. 8-15, 2017. 